\title{
Assessing Hotel Employee Knowledge on Risk Factors and Risk Management Procedures for Microbial Contamination of Hotel Water Distribution Systems
}

\author{
Brandon Leftwich ${ }^{1}$, Samuel T. Opoku ${ }^{1}$, Jingjing Yin ${ }^{2}$ and Atin Adhikari ${ }^{2, *(\mathbb{D}}$ \\ 1 Department of Health Policy and Community Health, Jiann-Ping Hsu College of Public Health, \\ Georgia Southern University, Statesboro, GA 30460, USA; b103096@georgiasouthern.edu (B.L.); \\ sopoku@georgiasouthern.edu (S.T.O.) \\ 2 Department of Biostatistics, Epidemiology, and Environmental Health Sciences, Jiann-Ping Hsu College of \\ Public Health, Georgia Southern University, Statesboro, GA 30460, USA; jyin@georgiasouthern.edu \\ * Correspondence: aadhikari@georgiasouthern.edu; Tel.: +1-912-478-2289
}

check for updates

Citation: Leftwich, B.; Opoku, S.T.; Yin, J.; Adhikari, A. Assessing Hotel Employee Knowledge on Risk Factors and Risk Management Procedures for Microbial Contamination of Hotel Water Distribution Systems. Int. J. Environ. Res. Public Health 2021, 18, 3539. https://doi.org/10.3390/ ijerph18073539

Academic Editor: Panagiotis Karanis

Received: 2 February 2021

Accepted: 25 March 2021

Published: 29 March 2021

Publisher's Note: MDPI stays neutral with regard to jurisdictional claims in published maps and institutional affiliations.

Copyright: (C) 2021 by the authors. Licensee MDPI, Basel, Switzerland. This article is an open access article distributed under the terms and conditions of the Creative Commons Attribution (CC BY) license (https:/ / creativecommons.org/licenses/by/ $4.0 /)$.

\begin{abstract}
Water management plans (WMPs), sometimes referred to as risk management plans (RMPs) or water safety plans (WSPs), are not mandatory for hotels in many countries of the world, including he US. As such, many hotel personnel are uninformed of WMPs and the precautions to take if their hotel water system is compromised. The purpose of this study was to identify hotel personnel's knowledge and practices of WMPs through a survey incorporating the Health Belief Model (HBM). Data were collected from 59 hotels within Fulton County, Georgia, USA, through a questionnaire, and questions were developed tailored to the HBM. Significant associations were found between the perceived susceptibility of contracting a waterborne illness and WMP for hotel personnel as well as between cues to action and having a WMP in general linear models $(p \leq 0.05)$. The study concludes that many key personnel are not aware of WMPs. Many hotel facilities do not have a plan in place, and some facilities are unaware of a current plan is in place. The study findings provide insight into the importance of WMPs and the risk factors associated with microbial contamination in a hotel building's plumbing system. Future research and potential law change should be emphasized to increase hotel employees' and owner's WMP knowledge.
\end{abstract}

Keywords: health belief model; hotels; water safety plans; Legionella; microbial contamination

\section{Introduction}

Water safety refers to the availability of good and affordable drinking water. Water management plans (WMPs) or water safety plans (WSP), which were first introduced by the World Health Organization (WHO), are aimed at ensuring safety and decrease in contamination of water supply in both developing and developed countries [1,2]. These plans have become necessary, especially in developed countries, due to recent incidences of water contamination [3]. Currently, there are no mandatory guidelines or procedures for hotels and tourist facilities in the US and many countries of the world if the facility's water system has been compromised by microbial contamination.

Extensive piping lines and complex plumbing in water systems of hotels may result in variability of temperature and stimulate biofilm accumulation, which collectively may favor the growth and proliferation of opportunistic and pathogenic microorganisms, including Legionella spp. [4,5]. These plumbing-related microorganisms can pose a serious public health risk. Several previous studies have reported Legionella contamination in hotel water distribution systems. For example, a study conducted in Greece reported that 20.8\% of the water distribution systems in 385 Greek hotels were positive for Legionella spp. [6]. Another study from Southwestern Greece reported the presence of Legionella in 36\% of water distribution systems in hotels [7]. Two other studies conducted in Italy observed 
percentages of Legionella contamination ranging from 63.6\% [8] to 75\% [5] in 11 and 40 Italian hotels, respectively. These studies considered culture-based methods for Legionella detection. When PCR-based methods were used, 74\% of 19 Italian hotels showed positive results for Legionella contamination in their water, and the authors of this study demonstrated that culture-based methods could underestimate the contaminations [9]. A recent study of 2020 investigated the prevalence of Legionella contamination and its molecular diversity in 168 hotels and resorts across Israel [10] and found that out of 2830 samples tested, $470(17 \%)$ obtained from 102 different premises (60\% of hotels) were positive for Legionella spp. The most frequently contaminated water sources in this study were cooling towers (38\%), followed by faucets, hot tubs, water lines, and storage tanks (14-17\% each).

Travel-related Legionella cases and transmissions in hotels were reported previously [11]. Travel-associated Legionnaires' disease was reported in more than 20 European countries, including the United Kingdom, Italy, France, and the Netherlands [12]. Travel-associated Legionella cases were also reported in the United States [11,13-15], Canada, and Australia $[16,17]$. Barskey et al. [15] recently reported that out of 12,200 Legionnaires' disease cases reported among US residents between 2015 and 2016, 12.3\% were travel-associated. Rasheduzzaman et al. [18] reviewed the hotel and non-hotel-associated Legionnaires' disease in Europe from 2000 to 2010 and found that out of a total of 7974 reported travelassociated Legionnaires' disease by different researchers, 7869 cases were hotel-associated, which represent about $99 \%$ of the reported travel-associated cases. All these findings underscore the importance of a WMP for controlling Legionella infections in hotels and tourist facilities.

In the US state of Georgia, the Georgia Department of Public Health (DPH) has recommendations for tourist accommodations after there was a Legionella report [19]. They have an immediate Legionella reporting contact (1-866-PUB-HLTH or 1-866-782-4584) for healthcare facilities, but no such hotline is available for hotels and tourist facilities. The DPH developed the Georgia Legionellosis control and investigation manual, which is used for investing an outbreak. Moreover, the DPH states that the health authority should provide the facility with educational material about the prevention of Legionella for tourist accommodations, including the Centers for Disease Control and Prevention (CDC) Water Management Program Toolkit [19]. The facility should implement a water management plan to prevent Legionella, per CDC recommendations. If the facility had a WMP in place, they should review the plan and revise it as needed [19]. However, many hotel owners, managers, and employees are not aware of what precautions to take if their hotel water system is compromised. This lack of knowledge can hinder their proactive roles in helping to raise awareness about the water quality standards and implementing these standards in Georgia hotels and tourist accommodations.

This study was intended to identify the gaps between limited knowledge of WMPs among hotel employees and the increased need for water safety plans for hotel facilities, which can ensure a safe environment for the public. The purpose of this study was to assess hotel employee knowledge on risk management procedures and risk factors for potential microbial contamination of Georgia hotel water distribution systems through a questionnaire survey incorporating the Health Belief Model (HBM) [20], which is one of the most widely used psychosocial approaches to explaining health-related behavior.

\section{Materials and Methods}

\subsection{Sample and Population}

The target population in this study includes all hotel facilities permitted through the Georgia Department of Public Health, in the Fulton County Health District. Fulton County is the most populous county of the state of Georgia, and its county seat is Atlanta, the state capital. A simple random sampling method was conducted to obtain a sample of 150 out of 260 hotels within Fulton County. To qualify for this study, the tourist accommodation facility must be permitted through the Georgia Department of Public Health. Participants must be employed by the respective facility. Data collection was accomplished through the 
means of survey questionnaires. These surveys were conducted face-to-face to help to reduce non-response. The reiteration of confidentiality was stressed to the staff to help to reduce the risk of response bias. The researcher was present to administer the questionnaire and to clarify any questions the participants had regarding the Survey.

\subsection{Instrumentation}

A 5-point Likert scale was used in the Survey, as the format is "often used in hospitality and tourism studies and tends to be favored over more complex scales in mail surveys" [21]. The authors of this research developed the survey. The study survey was formulated using validated questionnaires that used the HBM as an instrument to assess workers beliefs about using personal protective equipment [22] questionnaires that used for the implementation of the environmental management system [23], and a survey that addressed the attitudes of hotel managers in regard to environmental management [24].

The measurement scale consisted of the following: $1=$ Strongly Disagree, $2=$ Disagree, $3=$ Neutral, $4=$ Agree, $5=$ Strongly Agree. Background information for the corresponding hotels, such as the size, ownership, facility type, and other relevant information were requested. Questionnaires were sent to 1 of 4 personnel: (1) the owner; (2) the maintenance engineer, (3) the lead housekeeper, and (4) the lead manager of each hotel. These are the personnel who are usually involved in planning and implementing WMPs in a hotel.

The HBM was used in this study to assess hotel employees' attitudes and knowledge toward water management plans to get a better understanding of what barriers are in place. The Survey consisted of 2 sections. The 1st section consisted of general questions that pertain to the specific characteristics of the tourist accommodation, such as the age of the structure, type of facility (hotel, RV park, Bed and Breakfast, etc.), and general maintenance knowledge and attitudes. The next section consisted of questions tailored to the HBM [21]. Questions were developed to assess the six constructs of the HBM. These constructs include perceived susceptibility, perceived severity, perceived benefits, perceived barriers, cues to action, and self-efficacy. The Survey comprised 49 total questions.

\subsection{Data Collection}

Data were gathered over a three-month period (November 2019-January 2020). The researchers recruited hotel facilities via phone, email, and facility visits. Potential participants were provided a consent form that explained the purpose of the Survey along with reinsurance of confidentiality and the Survey being completely voluntary. If hotel personnel agreed, surveys were administered at the hotel location that was selected to participate. All data were collected specifically for research purposes (through our university Institutional Review Board approved protocol) and identifiable by study ID number only.

\subsection{Data Analysis}

Statistical software that was used for data analysis was the Statistical Analysis SystemUniversity Edition program, 2020 (SAS). To measure internal consistency and reliability, the Cronbach's alpha data was used. The Chi-square test was used to analyze categorized variables. The statistical significance was shown with $p$-values less than or equal to 0.05 .

\section{Results}

\subsection{Descriptive Analysis of Data}

In total, 50 out of 150 hotel facilities participated in this study, equating to a $33 \%$ response rate. All the participants were classified as hotel-motel establishments. In total, 3 out of the 50 facilities stated that their facility had experienced a waterborne outbreak. The age of the establishments in the sample size consisted as follows: $4 \%$ were $0-10$ years of age, $24 \%$ were aged $11-15,12 \%$ were $16-20,36 \%$ were $21-30$, and $24 \%$ were aged 31 and older.

Room capacity was assessed for each hotel establishment. This variable helps to gauge the size of each hotel. No hotels that participated had a room capacity of 0-25 rooms. In total, 
$6 \%$ of hotels had a room capacity of $26-50$ rooms, $40 \%$ had a capacity of $51-75$ rooms, $34 \%$ with a capacity of 76-100, and $20 \%$ of the facilities had rooms more than 100 . Participants within the study consisted of four occupancies: owner (6\%), manager (42\%), lead engineer (34\%), and lead housekeeper at $18 \%$.

\subsection{Knowledge of Water Management Plans (WMP) among Participants}

According to collected data, 44\% stated that they are not aware of a WMP, and 56\% stated "yes". Next, 34\% responded with "yes" to if their respective facility has a WMP, while $44 \%$ answered "no" and $22 \%$ "did not know". During the event of a water outage, half of the participants stated that their facility has emergency guidelines in place for such events, and 16\% stated that they "did not know" and 18\% stated "no". An encouraging 92\% of the respondents replied "yes" when asked if they had heard of a Boiled Water Advisory. All these responses are presented in Table 1.

Table 1. Awareness and guidelines against waterborne illness among hotel employees.

\begin{tabular}{|c|c|c|}
\hline Item & Frequency $(N)$ & Percentage $(\%)$ \\
\hline \multicolumn{3}{|c|}{ Have you heard of a WMP? } \\
\hline Yes & 28 & 56.0 \\
\hline No & 22 & 44.0 \\
\hline \multicolumn{3}{|c|}{ Does your facility have a WMP? } \\
\hline Yes & 17 & 34.0 \\
\hline No & 22 & 44.0 \\
\hline Don't Know & 11 & 22.0 \\
\hline \multicolumn{3}{|c|}{$\begin{array}{l}\text { Does your facility have emergency guidelines and or procedures in the event of a } \\
\text { water outage? }\end{array}$} \\
\hline Yes & 16 & 32.0 \\
\hline No & 25 & 50.0 \\
\hline Don't Know & 9 & 18.0 \\
\hline \multicolumn{3}{|c|}{ Have you heard of a Boil Water Advisory? } \\
\hline Yes & 46 & 92.0 \\
\hline No & 4 & 8.0 \\
\hline \multicolumn{3}{|c|}{$\begin{array}{l}\text { Does your facility have emergency guidelines and or procedures during an event of a } \\
\text { Boil Water Advisory? }\end{array}$} \\
\hline Yes & 25 & 50.0 \\
\hline No & 9 & 18.0 \\
\hline Don't know & 16 & 32.0 \\
\hline
\end{tabular}

It is imperative to have a designated staff member to ensure risk factors are limited or removed when monitoring a water system for a building. For the participants, $28 \%$ responded "no", 66\% answered "yes", and 6\% responded "don't know" to if their facility has designated personnel/staff for routine maintenance of your buildings' water system.

Cooling towers, decorative fountains, swimming pools, and spas have been directly linked to waterborne outbreaks when these items have been neglected and or poorly maintained. Only $6 \%$ of the hotels had cooling towers. Only $28 \%$ of the hotels had decorative fountains. Most of the hotels had a swimming pool at their facility (78\%). In conjunction, $58 \%$ of the hotels had a spa that is not drained between use. During nonvacation seasons, many hotels have rooms that are not occupied for an extended period; $30 \%$ of the hotels stated that they had rooms that are unoccupied for an extended period during their "slow seasons", which could be a risk factor for bacterial growth in the premise plumbing fixtures [25]. 


\subsection{Health Belief Model Data Analyses}

Section 2 of the Survey consisted of questions that are tailored to the constructs of the HBM. Participants were given five possible selections to choose on their beliefs toward specific topics. The options were strongly agree, agree, neither, disagree, and strongly disagree.

\subsubsection{Perceived Susceptibility}

The first construct was perceived susceptibility. The participants were asked five questions to assess their susceptibility to a waterborne illness. Ten percent believed the chances of a waterborne outbreak occurring at their facility are high. Twenty-four stated that they agreed and or strongly agreed that they worry about their guests and staff contracting a waterborne illness at their facility. Participants were asked if they felt that there is a good chance of getting a waterborne illness during their career. Twelve percent either agreed or strongly agreed. Lastly, $60 \%$ of the participants agreed or strongly agreed that a waterborne illness could be prevented by developing proper maintenance procedures for their facilities' water/plumbing system. See Table 2 for further detail.

Table 2. Perceived susceptibility of waterborne illnesses among hotel employees.

\begin{tabular}{|c|c|c|c|}
\hline Item & Response & Frequency $(N)$ & Percentage $(\%)$ \\
\hline \multirow{5}{*}{$\begin{array}{l}\text { I believe the chances of a waterborne outbreak occurring at my facility } \\
\text { is great }\end{array}$} & Strongly Agree & 3 & 6.0 \\
\hline & Agree & 2 & 4.0 \\
\hline & Neither & 18 & 36.0 \\
\hline & Disagree & 14 & 28.0 \\
\hline & Strongly Disagree & 14 & 28.0 \\
\hline \multirow{5}{*}{ I worry about my guest and staff getting a waterborne illness } & Strongly Agree & 4 & 8.0 \\
\hline & Agree & 8 & 16.0 \\
\hline & Neither & 10 & 20.0 \\
\hline & Disagree & 13 & 26.0 \\
\hline & Strongly Disagree & 15 & 50.0 \\
\hline \multirow{5}{*}{$\begin{array}{l}\text { I feel that there is a good chance of getting a waterborne illness during } \\
\text { my career. }\end{array}$} & Strongly Agree & 5 & 10.0 \\
\hline & Agree & 1 & 2.0 \\
\hline & Neither & 8 & 16.0 \\
\hline & Disagree & 13 & 26.0 \\
\hline & Strongly Disagree & 25 & 46.0 \\
\hline \multirow{5}{*}{$\begin{array}{l}\text { I know other hotel facilities that had a waterborne outbreak at their } \\
\text { facility }\end{array}$} & Strongly Agree & 9 & 18.0 \\
\hline & Agree & 10 & 20.0 \\
\hline & Neither & 10 & 20.0 \\
\hline & Disagree & 9 & 18.0 \\
\hline & Strongly Disagree & 12 & 24.0 \\
\hline \multirow{5}{*}{$\begin{array}{l}\text { I can prevent a waterborne illness by developing proper maintenance } \\
\text { procedures for my facilities water/plumbing system }\end{array}$} & Strongly Agree & 18 & 36.0 \\
\hline & Agree & 12 & 24.0 \\
\hline & Neither & 8 & 16.0 \\
\hline & Disagree & 7 & 14.0 \\
\hline & Strongly Disagree & 5 & 10.0 \\
\hline
\end{tabular}




\subsubsection{Perceived Severity}

Hotel worker participants answered questions pertaining to their beliefs of severity in relation to a waterborne illness outbreak that their facility. In response to the first question asked, "The thought of my hotel causing a waterborne outbreak concerns me," $74 \%$ agreed or strongly agreed to that statement. Forty-eight percent strongly agreed that if a waterborne illness occurred at their facility, the facility's reputation would be ruined. Fifty-two percent believed that their financial security would be ruined if an outbreak occurred at their facility. See Table 3 for further detail.

Table 3. Perceived severity of waterborne illnesses among hotel employees.

\begin{tabular}{|c|c|c|c|}
\hline Item & Response & Frequency $(N)$ & Percentage $(\%)$ \\
\hline \multirow{5}{*}{ The thought of my hotel causing a waterborne outbreak concerns me } & Strongly Agree & 18 & 36.0 \\
\hline & Agree & 19 & 38.0 \\
\hline & Neither & 7 & 14. \\
\hline & Disagree & 4 & 8.0 \\
\hline & Strongly Disagree & 2 & 4.0 \\
\hline \multirow{5}{*}{$\begin{array}{l}\text { If a waterborne illness occurs at my facility, my facility reputation } \\
\text { would be ruined }\end{array}$} & Strongly Agree & 4 & 2.0 \\
\hline & Agree & 8 & 6.0 \\
\hline & Neither & 10 & 16.0 \\
\hline & Disagree & 13 & 28 \\
\hline & Strongly Disagree & 15 & 48.0 \\
\hline \multirow{5}{*}{$\begin{array}{l}\text { Financial security will be endangered if a waterborne outbreak occurs } \\
\qquad \text { at my facility }\end{array}$} & Strongly Agree & 14 & 28.0 \\
\hline & Agree & 12 & 24.0 \\
\hline & Neither & 12 & 24.0 \\
\hline & Disagree & 11 & 22.0 \\
\hline & Strongly Disagree & 1 & 2.0 \\
\hline \multirow{5}{*}{$\begin{array}{l}\text { I believe my staff and guests could die prematurely if they contract a } \\
\text { waterborne illness at my facility }\end{array}$} & Strongly Agree & 15 & 30.0 \\
\hline & Agree & 6 & 12.0 \\
\hline & Neither & 6 & 12.0 \\
\hline & Disagree & 12 & 24.0 \\
\hline & Strongly Disagree & 11 & 22.0 \\
\hline
\end{tabular}

\subsubsection{Perceived Benefits}

To gauge how participants felt they would benefit from having a WMP, a series of questions was asked. In response to the question, "Having a water management plan will help reduce the risk of a waterborne outbreak from occurring," $70 \%$ agreed and strongly agreed. Next, $84 \%$ agreed and strongly agreed that having a water management plan ensures that their staff and guests are not exposed to waterborne contaminants. Lastly, 70\% of the participants agreed that a WMP would be beneficial to their facility. See Table 4 for results. 
Table 4. Perceived benefits of having a water management plan (WMP).

\begin{tabular}{|c|c|c|c|}
\hline Item & Response & Frequency $(N)$ & Percentage $(\%)$ \\
\hline \multirow{5}{*}{$\begin{array}{l}\text { Having a water management plan will help reduce the risk of a } \\
\text { waterborne outbreak from occurring }\end{array}$} & Strongly Agree & 20 & 40.0 \\
\hline & Agree & 15 & 30.0 \\
\hline & Neither & 8 & 16.0 \\
\hline & Disagree & 6 & 12.0 \\
\hline & Strongly Disagree & 1 & 2.0 \\
\hline \multirow{5}{*}{$\begin{array}{l}\text { Having a water management plan ensures that my staff and guests are } \\
\text { not exposed to waterborne contaminates }\end{array}$} & Strongly Agree & 23 & 46.0 \\
\hline & Agree & 19 & 38.0 \\
\hline & Neither & 7 & 14.0 \\
\hline & Disagree & 1 & 2.0 \\
\hline & Strongly Disagree & 0 & 0.0 \\
\hline \multirow{5}{*}{$\begin{array}{l}\text { The implementation of a water safety plan will be beneficial to } \\
\text { my facility }\end{array}$} & Strongly Agree & 21 & 42.0 \\
\hline & Agree & 14 & 28.0 \\
\hline & Neither & 8 & 16.0 \\
\hline & Disagree & 6 & 12.0 \\
\hline & Strongly Disagree & 1 & 2.0 \\
\hline
\end{tabular}

\subsubsection{Perceived Barriers}

Barriers to the implementation of WMP were assessed. When involving staff, $58 \%$ claimed to not have enough staff to implement and maintain a water safety plan. Furthermore, $64 \%$ agreed that having a WMP is time-consuming. For additional current resources, $68 \%$ agreed that they lack knowledge of the American Society of Heating, Refrigerating and Air-Conditioning Engineers (ASHRAE) Standard 188 and the CDC Water Management Plan Toolkit. In relation to enforcement, $66 \%$ of the participants stated that they do not have a WMP because it is not mandatory. When asked if the lack of financial support for maintaining a WMP was an issue, $52 \%$ agreed. In total, $62 \%$ agreed that lack of training for staff to maintain a WPM was an issue. Seventy-two percent agreed that the lack of explanation of concepts and the need for more guidance on the public health aspect of water safety plan were a barrier. See Table 5 for results.

Table 5. Perceived barriers preventing implementation of a WMP.

\begin{tabular}{|c|c|c|c|}
\hline Item & Response & Frequency $(N)$ & Percentage $(\%)$ \\
\hline \multirow{5}{*}{$\begin{array}{l}\text { I don't have enough staff to implement and maintain a water } \\
\text { safety plan }\end{array}$} & Strongly Agree & 14 & 28.0 \\
\hline & Agree & 15 & 30.0 \\
\hline & Neither & 13 & 26.0 \\
\hline & Disagree & 5 & 10.0 \\
\hline & Strongly Disagree & 3 & 6.0 \\
\hline \multirow{5}{*}{ Implementing a water safety plan is time-consuming } & Strongly Agree & 18 & 36.0 \\
\hline & Agree & 14 & 28.0 \\
\hline & Neither & 7 & 14.0 \\
\hline & Disagree & 4 & 8.0 \\
\hline & Strongly Disagree & 7 & 14.0 \\
\hline
\end{tabular}


Table 5. Cont.

\begin{tabular}{c}
\hline Item \\
\hline Do we lack an understanding of ASHRAE standard 188 and the CDC \\
water management plan toolkit?
\end{tabular}

I don't have a water safety plan because it is not mandatory

We lack the financial support to maintain a water management plann

\begin{tabular}{|c|c|c|}
\hline Response & Frequency $(N)$ & Percentage (\%) \\
\hline Strongly Agree & 19 & 38.0 \\
\hline Agree & 15 & 30.0 \\
\hline Neither & 8 & 16.0 \\
\hline Disagree & 5 & 10.0 \\
\hline Strongly Disagree & 3 & 6.0 \\
\hline Strongly Agree & 14 & 28.0 \\
\hline Agree & 19 & 38.0 \\
\hline Neither & 1 & 2.0 \\
\hline Disagree & 8 & 16.0 \\
\hline Strongly Disagree & 8 & 16.0 \\
\hline Strongly Agree & 14 & 28.0 \\
\hline Agree & 12 & 24.0 \\
\hline Neither & 14 & 28.0 \\
\hline Disagree & 5 & 10.0 \\
\hline Strongly Disagree & 5 & 10.0 \\
\hline Strongly Agree & 19 & 38.0 \\
\hline Agree & 12 & 24.0 \\
\hline Neither & 8 & 16.0 \\
\hline Disagree & 6 & 12.0 \\
\hline Strongly Disagree & 5 & 10.0 \\
\hline Strongly Agree & 21 & 42.0 \\
\hline Agree & 15 & 30.0 \\
\hline Neither & 7 & 14.0 \\
\hline Disagree & 3 & 6.0 \\
\hline Strongly Disagree & 4 & 8.0 \\
\hline Strongly Agree & 6 & 12.0 \\
\hline Agree & 5 & 10.0 \\
\hline Neither & 9 & 18.0 \\
\hline Disagree & 14 & 28.0 \\
\hline Strongly Disagree & 16 & 32.0 \\
\hline
\end{tabular}

\subsubsection{Cues to Action}

To assess what triggers are needed for the decision-making process to start the implementation of a WMP, questions for cues to action were asked to the participants. See Table 6 below. The following percentages are what participants stated they agreed/strongly agreed with. Receiving more encouragement from the local health authority to implement a water safety plan is important (86\%). Regular and frequent education on the importance of water safety plans will help with implementation (72\%). Having a simple method to implement a water safety plan will increase my chances of maintaining one (90\%). Provided training will encourage our facility to implement water safety plans (86\%). I am interested in water safety plans because I do not want my staff and guest exposed to any waterborne diseases (90\%). 
Table 6. Cues to action for hotel employees to implement a WMP.

\begin{tabular}{|c|c|c|c|}
\hline Item & Response & Frequency $(N)$ & Percentage (\%) \\
\hline \multirow{5}{*}{$\begin{array}{l}\text { Receiving more encouragement from the local health authority to } \\
\text { implement a water safety plan is important }\end{array}$} & Strongly Agree & 28 & 56.0 \\
\hline & Agree & 15 & 30.0 \\
\hline & Neither & 5 & 10.0 \\
\hline & Disagree & 2 & 4 \\
\hline & Strongly Disagree & 0 & 0 \\
\hline \multirow{5}{*}{$\begin{array}{l}\text { Regular and frequent education on the importance of water safety } \\
\text { plans will help with implemeantation. }\end{array}$} & Strongly Agree & 27 & 54.0 \\
\hline & Agree & 9 & 18.0 \\
\hline & Neither & 12 & 24.0 \\
\hline & Disagree & 1 & 2.0 \\
\hline & Strongly Disagree & 1 & 2.0 \\
\hline \multirow{5}{*}{$\begin{array}{l}\text { Having a simple method to implement a water safety plan will increase } \\
\text { my chances of maintaining one. }\end{array}$} & Strongly Agree & 31 & 62.0 \\
\hline & Agree & 14 & 28.0 \\
\hline & Neither & 5 & 10.0 \\
\hline & Disagree & 0 & 0.0 \\
\hline & Strongly Disagree & 0 & 0.0 \\
\hline \multirow{5}{*}{$\begin{array}{l}\text { Provided training will encourage our facility to implement water } \\
\text { safety plans }\end{array}$} & Strongly Agree & 22 & 44.0 \\
\hline & Agree & 21 & 42.0 \\
\hline & Neither & 7 & 14.0 \\
\hline & Disagree & 0 & 0.0 \\
\hline & Strongly Disagree & 0 & 0.0 \\
\hline \multirow{5}{*}{$\begin{array}{l}\text { I am interested in water safety plans because I do not want my staff } \\
\text { and guest exposed to any waterborne diseases }\end{array}$} & Strongly Agree & 27 & 54.0 \\
\hline & Agree & 18 & 36.0 \\
\hline & Neither & 5 & 10.0 \\
\hline & Disagree & 0 & 0.0 \\
\hline & Strongly Disagree & 0 & 0.0 \\
\hline
\end{tabular}

\subsubsection{Self- Efficacy}

Self-efficacy questions were asked to the participants to gauge the level of maintaining a WMP at their respective facilities. Participants agreed to the following questions: Once I receive more education on water safety plans, I will be more comfortable in implementing the program (80\%). The results can be seen below in Table 7 .

Table 7. Self-efficacy of hotel employees to maintain a WMP.

\begin{tabular}{ccccc}
\hline Item & Response & Frequency (N) & Percentage (\%) \\
\hline & Strongly Agree & 20 & 40.0 \\
\cline { 2 - 5 } $\begin{array}{c}\text { Once I receive more education on water safety plans, I will be more } \\
\text { comfortable in implementing the program }\end{array}$ & Agree & 20 & 40.0 \\
\cline { 2 - 5 } & Neither & 9 & 18.0 \\
\cline { 2 - 5 } & Sisagree & 0.0 & 2.0 \\
\hline
\end{tabular}


Table 7. Cont.

\begin{tabular}{|c|c|c|c|}
\hline Item & Response & Frequency $(N)$ & Percentage $(\%)$ \\
\hline \multirow{5}{*}{$\begin{array}{l}\text { I am confident that maintaining a water safety plan will help prevent a } \\
\text { waterborne illness outbreak at my facility }\end{array}$} & Strongly Agree & 20 & 40.0 \\
\hline & Agree & 15 & 30.0 \\
\hline & Neither & 12 & 24.0 \\
\hline & Disagree & 2 & 4.0 \\
\hline & Strongly Disagree & 1 & 2.0 \\
\hline \multirow{5}{*}{ I can train my staff to maintain records for water safety plans } & Strongly Agree & 17 & 34.0 \\
\hline & Agree & 13 & 26.0 \\
\hline & Neither & 13 & 26.0 \\
\hline & Disagree & 6 & 12.0 \\
\hline & Strongly Disagree & 1 & 2.0 \\
\hline \multirow{5}{*}{$\begin{array}{l}\text { I am confident that I can manage the additional duty of implementing } \\
\text { a water safety plan. }\end{array}$} & Strongly Agree & 16 & 32.0 \\
\hline & Agree & 14 & 28.0 \\
\hline & Neither & 14 & 28.0 \\
\hline & Disagree & 4 & 8.0 \\
\hline & Strongly Disagree & 2 & 4.0 \\
\hline \multirow{5}{*}{$\begin{array}{l}\text { It is our responsibility as hotel staff to provide safe potable water to } \\
\text { our guests. }\end{array}$} & Strongly Agree & 30 & 60.0 \\
\hline & Agree & 16 & 32.0 \\
\hline & Neither & 4 & 8.0 \\
\hline & Disagree & 0 & 0.0 \\
\hline & Strongly Disagree & 0 & 0.0 \\
\hline
\end{tabular}

3.4. Relationship between Hotel Facilities with no WMPs and Perceived Susceptibility to Waterborne Illness

The general linear regression model was used to assess if there was a significant relationship between whether hotel facilities with or without WMP and perceived susceptibility of contracting a waterborne illness in a hotel establishment. A significant relationship was found between the perceived susceptibility of contracting a waterborne illness and WMP for hotel personnel, with the $p$-value resulting in less than 0.05 . In this event, we can positively conclude that having no WMP is associated with the workers' perceived susceptibility to a waterborne illness (Table 8). Compared to the baseline response, respondents who have a WMP are associated with larger perceived susceptibility scores, while respondents who answered "don't know" are not significantly different from the reference group with a $p$-value of 0.43 greater than 0.05 .

Table 8. The general linear model showing the relationship between WMP and perceived susceptibility.

\begin{tabular}{|c|c|c|c|c|c|}
\hline Source & DF & Sum of Squares & Mean Square & $F$ Value & $\operatorname{Pr}>F$ \\
\hline Model & 2 & 122.817 & 61.40 & 3.77 & 0.0302 \\
\hline Error & 47 & 764.962 & 16.27 & & \\
\hline Corrected Total & 49 & 887.780 & & & \\
\hline Parameter & Estimate & & Standard Error & $t$ Value & $\operatorname{Pr}>|t|$ \\
\hline Don't Know & 1.18181818 & B & 1.48977420 & 0.79 & 0.4316 \\
\hline Yes & 3.56149733 & B & 1.30276975 & 2.73 & 0.0088 \\
\hline $\mathrm{NO}$ & 0.00000000 & B & - & - & - \\
\hline
\end{tabular}




\subsection{Correlation between Cues to Action and Implementation of WMPs}

The general linear model was used to analyze the relationship between cues to action and the implementation of having a WMP. A significant association was determined between cues to action and having a WMP, with a $p$-value less than 0.05 . Increased cues to action are associated with an increased likelihood of WMP implementation (Table 9).

Table 9. The general linear model showing the relationship between WMP and cues to action.

\begin{tabular}{cccccc}
\hline Parameter & Estimate & & Standard Error & $t$ Value & Pr $>|\mathbf{t}|$ \\
\hline Don't Know & 0.31818182 & B & 1.01774586 & 0.31 & 0.7779 \\
Yes & 2.84759358 & B & 0.88999294 & 3.20 & 0.0025 \\
NO & 0.00000000 & B & - & - & - \\
\hline
\end{tabular}

The "NO" response is set as the comparison group; the "don't know" response is not statistically significant because its $p$-value (0.7559) is greater than the significance level of 0.05 . However, there is a statistically significant association between cues to action and hotel respondents with a WMP, having a $p$-value of 0.0025 .

\subsection{Perceived Benefits and Barriers Identified by Hotel Workers for Implementing WMPs}

Over $70 \%$ of the respondents responded favorably to each perceived benefit question in the questionnaire. When combining "disagree" with "strongly disagree" results and "agree" with "strongly agree" results in the barrier questions, over $50 \%$ agreed with seven out of the eight barriers.

Finally, the internal consistency and reliability of survey questions were checked using the Cronbach Alpha Reliability test. The summative scores for each scale are provided in Table 10.

Table 10. The internal consistency and reliability of survey questions checked by the Cronbach Alpha Reliability test (summative scores for scales).

\begin{tabular}{ccc}
\hline Scale & Number of Items in Scale & Cronbach's Alpha \\
\hline perceived susceptibility & 5 & 0.67 \\
perceived severity & 4 & 0.70 \\
perceived benefits & 3 & 0.88 \\
perceived barriers & 8 & 0.71 \\
cues to action & 5 & 0.77 \\
self-efficacy & 5 & 0.83 \\
\hline
\end{tabular}

\section{Discussion}

There are several agencies that have developed resources and guidelines for WMPs in the US and abroad. Such agencies as the CDC, ASHRAE, and the World Health Organization (WHO) developed basic standards to help building owners to be protected from the risk of microbial contamination. Owners and managers of hotels and tourist accommodations with high biofilm risk complex plumbing systems should use WMPs to prevent the growth and spread of Legionella, and they should have adequate knowledge about these WMPs. However, according to this study, $68 \%$ of the respondents lack an understanding of what these agencies provide. With the lack of awareness of available resources and the general understanding of WMPs, this could also be a major contributor to having no WMP. These findings are closely similar to a study conducted by Chan [21], where the study aimed to investigate barriers to implement environmental management systems (EMS) in the hotel industry in Hong Kong. Similar to this study, lack of knowledge, lack of professional advice, lack of resources, and cost were identified in this study as barriers. The identified barriers also align with another similar study conducted in the UK [23]. These similar findings help to strengthen the need for further research to combat these barriers from the implementation of WMPs. 
Our findings indicate that regardless of the size of the building, water systems should have some type of water management plan to reduce the risk of water contamination through their plumbing system. Each facility must develop a WMP that is tailored to that specific building. Key hotel personnel who are responsible for implantation must consider (1) understanding the building's plumbing system, (2) identifying all areas of the plumbing endpoints, (3) ensuring all water equipment and fixtures are maintained and kept in a good state, (4) developing teams that are responsible for reducing stagnation of water, biofilm and mold buildup at water fixtures, (5) creating a maintenance log for all cleanings, checks, and services, and (6) developing an emergency plan in case of a water emergency, such as a boil water advisory or do not drink advisory. In addition, hotel personnel should pay attention to water temperature levels because Legionella spp. grows well in warm water, and many previous outbreaks were associated with hot water systems [26,27].

There are other types of facilities that are required to have a WMP to prevent the risk of illness to the public. The Centers for Medicare and Medicaid Services (CMS) released a survey and certification memo in June 2017 indicating all healthcare facilities should develop and adhere to ASHRAE-compliant water management programs to reduce the risk for Legionella and other pathogens in their water systems [19]. We think similar regulatory approaches should be considered for hotels and tourist facilities.

Overall, this study is unique compared to other studies on WMPs, as we used the HBM to help to identify barriers and predict the change of a facility's behavior for the implementation of a program. This approach is important due to the array of factors that are assessed not only at the broad company level but at the individual level. If behavior change is done at the induvial level, we hope to create change through an ecological effect.

There were a few possible limitations to the study. Response bias could have been a possibility for the study. Though the Survey was introduced and explained as confidential, voluntary, and for research purposes, many facilities were not comfortable with disclosing information to the researcher due to fear of job loss and negative publicity. Another limitation of the study was a low response rate of $33 \%$.

There are limited studies pertaining to WMPs for hotel facilities. We hope that our findings can aid future studies in this area. Overall, the results of this study have determined that the vast majority of hotel personnel are not aware of water management plans. As the surveys stated, many hotel facilities would implement a WMP if they knew more about it. This study shows that if awareness for the program is provided, it is more likely for the facility to implement the program. As we enter a world forever transformed by the current pandemic, health and safety programs will no longer be an afterthought. For example, new guidelines to help to slow the spread of COVID-19 will be in place for the foreseeable future as awareness of the severity of the disease has risen. Hence, the same can be done simultaneously for waterborne illnesses in hotels and tourist facilities. We believe this study, along with many others mentioned above, will serve as a guideline to show how our hotels and other service industries can win the trust of Georgians and other American people that their health is safe.

\section{Conclusions}

A significant relationship was found between cues to action and the implementation of having a WMP and also between the perceived susceptibility of contracting a waterborne illness and WMP for hotel personnel. The study concludes that if hotel personnel believe that they are susceptible to an outbreak, they will be more likely to implement a WMP. This solidifies the need for research to continue to ensure the health of our larger communities. It was encouraging to see that many of the participants who were not aware of WMPs became interested in learning more about the program during the time of recruitment of this study. If there is no push for further research and raising awareness, people will continue to be susceptible to another waterborne outbreak while they may be vacationing with loved ones, at a conference, or other circumstances that involve hotel stays. 
Author Contributions: Conceptualization, A.A., S.T.O., and B.L.; methodology, J.Y., B.L, S.T.O., and A.A..; formal analysis, B.L., and J.Y.; investigation, B.L.; data curation, B.L.; writing-original draft preparation, B.L., A.A., J.Y., and S.T.O; supervision, A.A. All authors have read and agreed to the published version of the manuscript.

Funding: This research received no external funding.

Institutional Review Board Statement: The study was conducted according to the guidelines of the Declaration of Helsinki, and approved by the Institutional Review Board of Georgia Southern University (protocol H19202, approval date: 20 August 2019).

Informed Consent Statement: Informed consent was obtained from all subjects involved in the study.

Data Availability Statement: All collected data are contained within the article.

Acknowledgments: The authors would like to thank all the hotel personnel who participated in this study.

Conflicts of Interest: The authors declare no conflict of interest.

\section{References}

1. World Health Organization (WHO). Guidelines for Drinking-Water Quality; WHO: Geneva, Switzerland, 2011 ; pp. 303-304.

2. WHO. Water, Sanitation and Hygiene Links to Health: Facts and Figures; WHO: Geneva, Switzerland, 2004.

3. Altmann, P.; Cunningham, J.; Dhanesha, U.; Ballard, M.; Thompson, J.; Marsh, F. Disturbance of cerebral function in people exposed to drinking water contaminated with aluminium sulphate: Retrospective study of the Camelford water incident. BMJ 1999, 319, 807-811. [CrossRef] [PubMed]

4. Yu, V.L. Legionella Surveillance: Political and Social Implications-A Little Knowledge Is a Dangerous Thing. J. Infect. Dis. 2002, 185, 259-261. [CrossRef] [PubMed]

5. Borella, P.; Montagna, M.T.; Stampi, S.; Stancanelli, G.; Romano-Spica, V.; Triassi, M.; Marchesi, I.; Bargellini, A.; Tatò, D.; Napoli, C.; et al. Legionella Contamination in Hot Water of Italian Hotels. Appl. Environ. Microbiol. 2005, 71, 5805-5813. [CrossRef]

6. Mouchtouri, V.; Velonakis, E.; Tsakalof, A.; Kapoula, C.; Goutziana, G.; Vatopoulos, A.; Kremastinou, J.; Hadjichristodoulou, C. Risk Factors for Contamination of Hotel Water Distribution Systems by Legionella Species. Appl. Environ. Microbiol. 2007, 73, 1489-1492. [CrossRef]

7. Fragou, K.; Kokkinos, P.; Gogos, C.; Alamanos, Y.; Vantarakis, A. Prevalence of Legionella spp. in water systems of hospitals and hotels in South Western Greece. Int. J. Environ. Health Res. 2012, 22, 340-354. [CrossRef]

8. Leoni, E.; De Luca, G.; Legnani, P.; Sacchetti, R.; Stampi, S.; Zanetti, F. Legionella waterline colonization: Detection of Legionella species in domestic, hotel and hospital hot water systems. J. Appl. Microbiol. 2004, 98, 373-379. [CrossRef]

9. Bonetta, S.; Bonetta, S.; Ferretti, E.; Balocco, F.; Carraro, E. Evaluation of Legionella pneumophila contamination in Italian hotel water systems by quantitative real-time PCR and culture methods. J. Appl. Microbiol. 2010, 108, 1576-1583. [CrossRef]

10. Yakunin, E.; Kostyal, E.; Agmon, V.; Grotto, I.; Valinsky, L.; Moran-Gilad, J. A Snapshot of the Prevalence and Molecular Diversity of Legionella pneumophila in the Water Systems of Israeli Hotels. Pathogens 2020, 9, 414. [CrossRef]

11. Cowgill, K.D.; Lucas, C.E.; Benson, R.F.; Chamany, S.; Brown, E.W.; Fields, B.S.; Feikin, D.R. Recurrence of Legionnaires Disease at a hotel in the United States Virgin Islands over a 20-Year Period. Clin. Infect. Dis. 2005, 40, 1205-1207. [CrossRef]

12. Beauté, J. Legionnaires' disease in Europe, 2011 to 2015. Eurosurveillance 2017, 22, 30566. [CrossRef]

13. Ahmed, S.S.; Hunter, C.M.; Garrison, L.E.; Turabelidze, M.D.; Kunz, J.; Mphtm, L.A. Legionnaires' Disease at a Hotel in Missouri, 2015: The Importance of Environmental Health Expertise in Understanding Water Systems. J. Environ. Ment. Health 2019, 81, 8-13.

14. Smith, P.; Moore, M.; Alexander, N.; Hicks, L.; O'Loughlin, R. Surveillance for travel-associated legionnaires disease-United States, 2005-2006. Morb. Mortal. Wkly. Rep. 2007, 56, 1261-1263.

15. Barskey, A.E.; Lackraj, D.; Tripathi, P.S.; Lee, S.; Smith, J.; Edens, C. Travel-associated cases of Legionnaires' disease in the United States, 2015-2016. Travel Med. Infect. Dis. 2021, 40, 101943. [CrossRef]

16. US Environmental Protection Agency (US EPA). Legionella: Human Health Criteria Document; US EPA EPA-822-R-99-001; US EPA: Washington, DC, USA, 1999.

17. Tobin, R.S.; Ewan, P.; Walsh, K.; Dutka, B. A survey of Legionella pneumophila in water in 12 Canadian cities. Water Res. 1986, 20, 495-501. [CrossRef]

18. Rasheduzzaman, M.; Singh, R.; Haas, C.N.; Gurian, P.L. Required water temperature in hotel plumbing to control Legionella growth. Water Res. 2020, 182, 115943. [CrossRef]

19. Georgia Legionellosis Control and Investigation Manual. Available online: https://dph.georgia.gov/environmental-health/ hotels-motels-and-campgrounds (accessed on 9 September 2020).

20. Strecher, V.J.; Rosenstock, I.M. The health belief model. Camb. Handb. Psychol. Health Med. 1997, 25, $113-117$.

21. Chan, E.S. Barriers to EMS in the hotel industry. Int. J. Hosp. Manag. 2008, 27, 187-196. [CrossRef] 
22. Wall, J.M. Development of a Health-Belief-Model-Based Instrument to Assess Worker Beliefs about Using Personal Protective Equipment. Ph.D. Thesis, Department of Health Promotion and Education, University of Utah, Salt Lake City, UT, USA, 2009.

23. Hillary, R. Environmental management systems and the smaller enterprise. J. Clean. Prod. 2004, 12, 561-569. [CrossRef]

24. Kirk, D. Attitudes to environmental management held by a group of hotel managers in Edinburgh. Int. J. Hosp. Manag. 1998, 17,33-47. [CrossRef]

25. Falkinham, J.O. Common Features of Opportunistic Premise Plumbing Pathogens. Int. J. Environ. Res. Public Health 2015, 12, 4533-4545. [CrossRef]

26. Barna, Z.; Kádár, M.; Kálmán, E.; Szax, A.S.; Vargha, M. Prevalence of Legionella in premise plumbing in Hungary. Water Res. 2016, 90, 71-78. [CrossRef] [PubMed]

27. Serrano-Suárez, A.; Dellundé, J.; Salvadó, H.; Cervero-Aragó, S.; Méndez, J.; Canals, O.; Blanco, S.; Arcas, A.; Araujo, R. Microbial and physicochemical parameters associated with Legionella contamination in hot water recirculation systems. Environ. Sci. Pollut. Res. 2013, 20, 5534-5544. [CrossRef] [PubMed] 